\title{
Analisis Perilaku Konsumen terhadap Keputusan Pembelian Buah-Buahan di Moena Fresh Bali
}

\author{
NI MADE SRI KESARI DHARMA PADMI, RATNA KOMALA DEWI, \\ I.G.A.A. LIES ANGGRENI
}

\author{
Program Studi Agribisnis, Fakultas Pertanian, Universitas Udayana \\ Jl. PB. Sudirman Denpasar 80323 \\ Email: srikesaridharmap@yahoo.com \\ ratnadewi61@ymail.com
}

\begin{abstract}
The Analysis of Consumers' Behavior Against The Decision on Purchasing Fruits in Moena Fresh
\end{abstract}

This research aimed to (1) analyze the process of decision making in purchasing fresh fruits in Moena Fresh, (2) analyze the factors which influence the consumers in deciding to purchase fruits in Moena Fresh. The data analysis method that were used were descriptive analysis to find out the process of decision making in purchasing the fruits and factor analysis to analyze the factors which influenced the consumers in deciding to purchase the fruits in Moena Fresh.

The results showed some of the steps that consumer passing through before purchasing, those were the recognition of needs, search of information, evaluation of alternatives, purchase, and post-purchase. Factors that influenced the consumers in deciding the purchasing of fresh fruits in Moena Fresh include external factor and internal factor. External factor that is environment factor that involves variable of freshness of the fruits, fruit hygiene, packaging, price of fruits, cleanliness of the rack, service of the store employees, store temperature, and the aroma of the store. Internal factor that is psychological factor that involves variable of the types of the fruits; and also individual differences factor consists of the income of the consumers. Suggestions that can be given that Moena Fresh pay attention to the availality of fruit on order to avoid a product void and consider other factors such as, advertising and situation of consumer psychology.

Keywords: modern retail, fruits, consumer behavior, purchasing decision

\section{Pendahuluan}

\subsection{Latar Belakang}

Seiring dengan perkembangan zaman yang terjadi di Indonesia, masyarakat cenderung memilih retail modern sebagai tempat berbelanja kebutuhan. Peralihan konsumen ke retail modern dikarenakan adanya perubahan gaya hidup masyarakat dan terbukanya peluang bisnis retail modern oleh pemerintah Indonesia (Wibowo, 2013). 
Perkembangan berbagai jenis retail modern yang terus meningkat mengakibatkan terjadinya persaingan antar retail modern. Salah satu perbandingan yang ada pada jenis retail modern yaitu perbandingan antara swalayan dengan specialty store. Kedua jenis retail modern ini memiliki kelebihan masing-masing dimana dengan adanya swalayan ini mempermudah masyarakat melakukan pembelian kebutuhan rumah tangga secara bersamaan sedangkan specialty store merupakan toko khusus yang menjual jenis barang tertentu. Apabila masyarakat hanyak terfokus pada satu jenis produk sebaiknya melakukan pembelian pada specialty store.

Salah satu produk yang ditawarkan oleh specialty store yaitu berupa kebutuhan pangan seperti sayuran dan buah-buahan. Komoditas hortikultura khususnya sayuran dan buah-buahan memegang bagian terpenting dari keseimbangan pangan yang dikonsumsi, sehingga harus tersedia setiap saat dalam jumlah yang cukup, mutu yang baik, aman dikonsumsi, harga yang terjangkau, serta dapat diakses oleh seluruh lapisan masyarakat (Dirjen Hortikultura, 2012).

Berdasarkan dari hasil Survei Sosial Ekonomi Nasional (Basis Data Konsumsi Pangan 2014) terdapat tiga jenis buah yang paling diminati oleh masyarakat Indonesia yaitu buah pisang, jeruk dan pepaya. Dilihat dari total konsumsi buahbuahan per kapita setiap tahunnya mengalami peningkatan, dimana pada tahun 2012 total konsumsi sebesar 16,163 kg kemudian pada tahun 2013 mengalami peningkatan konsumsi sebesar $0,988 \mathrm{~kg}$. Peningkatan ini terjadi lagi hingga tahun 2014 yaitu sebesar 1,88 kg. Peningkatan total konsumsi buah-buahan ini menjadikan kesempatan bagi perusahaan untuk mengembangkan bisnisnya dalam bidang penjualan buah-buahan.

Moena Fresh merupakan salah satu retail modern yang berada di Bali yang usahanya bergerak dibidang agribisnis khususnya pada produk hortikultura berupa buah-buahan. Berdasarkan informai perusahaan Moena Fresh, penjualan buah-buahan segar selama tiga tahun terakhir mengalami penurunan, dengan rata-rata penurunan penjualan sebesar dua persen (Moena Fresh, 2016). Oleh karena itu perlu dilakukan penelitian tentang Analisis Perilaku Konsumen terhadap Keputusan Pembelian Buahbuahan Segar di Moena Fresh.

\subsection{Tujuan}

Tujuan dari penelitian ini adalah untuk menganalisis proses pengambilan keputusan pembelian buah-buahan di Moena Fresh dan menganalisis faktor-faktor yang mempengaruhi konsumen dalam memutuskan pembelian buah-buahan di Moena Fresh.

\section{Metodologi Penelitian}

\subsection{Lokasi dan Waktu Penelitian}

Penelitian ini dilakukan di empat outlet Moena Fresh yaitu di outlet Panjer, outlet Diponogoro, outlet Tohpati, dan outlet Kesiman. Waktu penelitian ini dilakukan pada bulan Januari - Pebruari 2017. Pemilihan lokasi dilakukan secara 
purposive (sengaja) atas pertimbangan bahwa Toko Buah Moena Fresh merupakan salah satu retail yang menjual buah-buahan yang cukup dikenal sebagian masyarakat Bali.

\subsection{Metode pengumpulan data}

Jenis data yang digunakan dalam penelitian ini adalah data kuantitatif dan data kualitatif. Data kuantitatif yang digunakan berupa laporan penjualan selama tiga tahun terakhir dan data kualitiatif mencakup gambaran umum tempat penelitian, karakteristik responden, proses tahapan keputusan pembelian, dan faktor-faktor yang mempengaruhi keputusan pembelian. Pengumpulan data dilakukan dengan wawancara melalui memberikan daftar pertanyaan kepada konsumen Moena Fresh.

\subsection{Penentuan Sampel dan Teknik Pengambilan Sampel}

Jumlah populasi dalam penelitian ini tidak diketahui sehingga metode yang sesuai digunakan untuk penelitian ini adalah accidental sampling. Kriteria sampel yang digunakan adalah konsumen yang berbelanja di Moena Fresh yang sebagai pemberi keputusan pembelian.

Menurut Malhotra dalam Kusmintarti (2010), besarnya jumlah sampel yang diambil dapat ditentukan dengan cara mengalikan jumlah variabel dengan lima. Jumlah variabel yang digunakan dalam penelitian ini adalah 10, maka jumlah sampel ditetapkan 50 orang.

\subsection{Pengujian Kuisioner}

Uji validitas adalah suatu uji untuk menunjukkan tingkat-tingkat kevalidan atau keahlian suatu instrument (Arikunto, 2009). Berdasarkan uji validitas pada penelitian ini maka dapat dijelaskan bahwa 10 variabel yang digunakan menunjukkan bahwa nilai $\mathrm{r}$ hitung lebih besar $\mathrm{r}$ tabel dengan tingkat signifikan sebesar lima persen yang artinya bahwa 10 variabel tersebut valid.

Uji reliabilitas digunakan untuk mengetahui ketepatan alat evaluasi dalam mengukur (Arikunto, 2009). Jika nilai alpha lebih besar 0,80 ini mensugestikan seluruh item reliabel dan seluruh tes secara konsisten memiliki reliabilitas yang kuat (Binus University, 2014). Berdasarkan pada uji realibilitas penelitian ini maka dapat dijelaskan bahwa 10 variabel yang digunakan menunjukkan bahwa nilai Cronbach Alpha sebesar 0,806 yang menunjukkan bahwa ke 10 pernyataan memiliki realibilitas kuat. Pengujian validitas dan realibilitas instrument dalam penelitian ini menggunakan bantuan komputerisasi program software SPSS 20 for windows.

\subsection{Metode Analisis}

Pada tujuan penelitian pertama menggunakan analisis deskriptif untuk mengetahui proses keputusan dalam pembelian buah-buahan sedangkan penelitian kedua digunakan analisis faktor untuk mengetahui faktor-faktor yang mempengaruhi keputusan pembelian buah-buahan di Moena Fresh. 
Menurut Maholtra dalam Setyani (2006), secara matematis model dari analisis faktor adalah sebagai berikut :

$$
\mathrm{Fi}=W i^{1} X^{1}+W i^{2} X^{2}+\ldots \ldots . .+W i^{n} X^{n}
$$

Keterangan :

$\mathrm{Fi}=$ Estimasi faktor ke-i

$\mathrm{Wi}=$ Bobot atau koefisien skor faktor

$X^{n}=$ Variabel yang diamati

Variabel yang diamati adalah pendapatan $(\mathrm{x} 1)$, jenis buah $(\mathrm{x} 2)$, kesegaran buah (x3), kebersihan buah (x4), packaging (x5), harga (x6), kebersihan rak (x7), pelayanan pramuniaga $(\mathrm{x} 8)$, suhu ruangan $(\mathrm{x} 9)$, dan aroma ruangan $(\mathrm{x} 10)$.

Menurut Tenaya (2009), tahap-tahap dalam analisis faktor konfirmatori adalah sebagai berikut:

1. Menguji kelayakan secara keseluruhan variabel atau masing-masing variabel dengan menggunakan Bartlett test of sphericity untuk menguji variabel secara keseluruhan dan Anti-image correlation test menguji setiap variabel.

2. Melakukan proses factoring atau mereduksi item sehingga terbentuk faktor yang dapat mewakili setiap variabel asal. Faktor ditetapkan berdasarkan nilai eigenvalue, yaitu yang bernilai di atas satu. Kriteria signifikan yang ditetapkan adalah sigfinikansi praktis dimana loading di atas 0,5. Variabel dengan loading tertinggi dianggap lebih penting dan memiliki kontribusi terbesar untuk menamai faktor. Penamaan faktor bisa dilakukan dengan melihat variabel-variabel yang diwakili oleh faktor.

3. Setelah faktor terbentuk, maka dapat dilakukan analisis data lanjutan dengan menggunakan nilai skor faktor.

\section{Hasil dan Pembahasan}

\subsection{Karakteristik Konsumen}

Berdasarkan hasil penelitian, kategori umur konsumen yang berbelanja ke Moena Fresh sebanyak 52\% berasal dari kalangan dewasa awal. Mengenai karakteristik jenis kelamin dijelaskan bahwa konsumen yang berbelanja ke Moena Fresh lebih dominan perempuan dibandingkan dengan laki-laki, hal ini dapat dilihat dari jumlah pengunjung perempuan yang berbelanja ke Moena Fresh adalah sebanyak 56\%. Tingkatan pendidikan konsumen yang berbelanja buah-buahan di Moena Fresh sebanyak 70\% memiliki tingkat pendidikan tinggi (diploma/sarjana). Karakteristik konsumen berdasarkan pekerjaan sebanyak 58\% konsumen merupakan seorang karyawan swasta. Karakteristik pendapatan konsumen sebanyak 56\% tergolong memiliki pendapatan yang sangat tinggi. 


\subsection{Tahapan Pengambilan Keputusan Pembelian Buah-buahan di Moena Fresh}

Tahapan pengambilan keputusan konsumen dalam pembelian buah-buahan segar di Moena Fresh melewati beberapa tahapan-tahapan pengenalan kebutuhan, pencarian informasi, evaluasi alternatif, proses pembelian dan pasca pembelian.

1. Pengenalan kebutuhan

Berdasarkan hasil penelitian, seluruh konsumen yang berbelanja ke Moena Fresh mengatakan penting mengonsumsi buah-buahan dengan alasan bahwa buahbuahan memiliki banyak manfaat terutama untuk kesehatan tubuh. Pentingnya mengonsumsi buah-buahan bagi kesehatan tubuh membuat 50\% konsumen Moena Fresh ini sering melakukan pembelian buah-buahan setiap bulannya. Apabila dibandingkan dengan penelitian Delita (2008), kedua penelitian ini memiliki persamaan bahwa pentingnya mengonsumsi buah-buahan dan sayur-sayuran setiap hari karena alasan kesehatan.

2. Pengenalan Informasi

Berdasarkan hasil penelitian pada tahap pengenalan informasi, bahwa $76 \%$ konsumen Moena Fresh memperoleh informasi mengenai keberadaan Moena Fresh melalui anggota keluarga/temannya sendiri. Bentuk informasi ini dapat dikembangkan lagi melalui bentuk promo lainnya, seperti memanfaatkan sosial media untuk memberikan informasi mengenai ketersediaan dan harga buah serta promo yang diadakan Moena Fresh. Apabila dibandingkan dengan penelitian Delita (2008), terdapat perbedaan sumber informasi mengenai keberadaan toko. Sumber informasi yang diperoleh pada penelitian Delita yaitu langsung dari melihat keberadaan toko.

3. Evaluasi Alternatif

Berdasarkan hasil penelitian pada tahap evaluasi alternatif, dapat disimpulkan bahwa sebanyak 56\% konsumen lebih mempertimbangkan kualitas (warna, kesegaran, dan kebersihan) buah sebelum memutuskan melakukan pembelian. Berdasarkan hal ini maka kualitas buah harus selalu diperhatikan oleh pihak perusahaan untuk mempertahankan konsumennya. Apabila dibandingkan dengan penelitian Delita (2008), sedikit memiliki perbedaan dengan penelitian ini, dimana penelitian Delita mengutamakan atribut fisik sayuran dan diikuti dengan kenyamanan 4. Pembelian

Berdasarkan hasil penelitian pada tahap pembelian, dapat disimpulkan bahwa sebanyak 72\% konsumen memutuskan membeli buah-buahan di Moena Fresh berdasarkan atas situasi. Konsumen membeli buah berdasarkan atas selera dan kebutuhan mereka, dimana $74 \%$ konsumen memilih jenis buah lokal. Apabila harga buah-buahan di Moena Fresh mengalami kenaikan maka sebanyak 88\% konsumen akan tetap berbelanja buah-buahan di Moena Fresh dan apabila buah yang diinginkan oleh konsumen tidak tersedia maka sebanyak $60 \%$ konsumen akan berpaling atau membatalkan pembelian.

Apabila dibandingkan dengan penelitian Delita (2008), terlihat memiliki persamaan dan perbedaan dengan penelitian ini. Persamaan penelitian ini yaitu dalam 
memutuskan membeli buah atau sayuran didasarkan atas situasi dan apabila terjadinya kenaikan harga konsumen akan tetap membeli buah atau sayuran tersebut. Perbedaan penelitian ini apabila barang yang diinginkan tidak tersedia maka penelitian Delita memilih membeli sayuran jenis lain sedangkan pada penelitian ini sebagian besar memilih membatalkan pembelian.

5. Pasca Pembelian

Berdasarkan hasil penelitian diatas maka dapat dilihat bahwa sebanyak $88 \%$ konsumen merasa puas terhadap produk yang ditawarkan Moena Fresh dan seluruh konsumen berniat kembali melakukan pembelian di Moena Fresh. Hal ini dapat disimpulkan bahwa pada tahap pasca pembelian terdapat kepuasan yang dimiliki sebagian konsumen dan seluruh konsumen berniat untuk kembali lagi melakukan pembelian buah- buahan. Hal ini memiliki persamaan dengan penelitian Delita (2008), yang mengatakan bahwa responden sayuran segar menyatakan puas berbelanja di Foodmart dan berniat melakukan pembelian kembali

\subsection{Faktor-faktor yang Mempengaruhi Pengambilan Keputusan Pembelian Buah- buahan di Moena Fresh}

Di dalam penelitian ini variabel yang dianalisis,yaitu variabel pendapatan, jenis buah, kesegaran buah, kebersihan buah, packaging buah, harga, kebersihan rak buah, pramuniaga toko, suhu ruangan, dan aroma ruangan. Tahapan pertama dilakukan uji kelayakan terhadap 10 variabel lainnya dengan menggunakan Keiser-Meyer-Olkin Measure of Sampling Adequacy (KMO MSA).

Tabel 1.

KMO and Bartlett's Test

\begin{tabular}{llr}
\hline Kaiser-Meyer-Olkin Measure of Sampling Adequacy. &, 781 \\
& Approx. Chi-Square & 184,595 \\
Bartlett's Test of Sphericity & Df & 45 \\
& Sig. &, 000 \\
\hline
\end{tabular}

Berdasarkan pada tabel diatas, nilai KMO yang diperoleh 0,781 dengan nilai signifikansi sebesar 0,000. Maka dapat dikatakan bahwa secara keseluruhan variabel ini layak untuk dianalisis. Langkah selanjutnya adalah menganalisis setiap variabel untuk mengetahui variabel yang dapat diproses lebih lanjut dan variabel yang harus dikeluarkan. Variabel yang memiliki nilai MSA kurang dari 0,5 akan dikeluarkan dari analisis faktor. 
Tabel 2.

Tabel Anti Image Matrix

\begin{tabular}{llc}
\hline No & \multicolumn{1}{c}{ Variabel } & Nilai MSA \\
\hline 1 & Pendapatan & 0,536 \\
2 & Jenis Buah & 0,619 \\
3 & Kesegaran Buah & 0,768 \\
4 & Kebersihan Buah & 0,728 \\
5 & Packaging & 0,748 \\
6 & Harga & 0,851 \\
7 & Kebersihan Rak & 0,849 \\
8 & Pelayanan Pramuniaga & 0,845 \\
9 & Suhu Ruangan & 0,761 \\
10 & Aroma Ruangan & 0,847 \\
\hline
\end{tabular}

Berdasarkan pada Tabel 2, dijelaskan bahwa dari masing-masing variabel tersebut tidak ada variabel yang memiliki nilai MSA kurang dari 0,5 sehingga semua variabel dapat dianalisis ke proses selanjutnya.Kriteria suatu faktor yang dipertimbangkan oleh konsumen dalam keputusan membeli buah-buahan di Moena Fresh, dapat diketahui dengan melihat nilai eigenvalue dari suatu faktor. Faktor yang dipertimbangkan konsumen dalam keputusan membeli buah-buahan harus memiliki nilai eigenvalue yang lebih besar atau sama dengan satu. Berikut adalah angka Eigenvalue dan Proporsi Varians dari tiap faktor yang merupakan bentuk sederhana dari tabel Total Variance Explained dan disajikan dalam Tabel 3.

Tabel 3.

Total Variance Explained

\begin{tabular}{ccc}
\hline Faktor & Eigenvalues & Persentase of Variance \\
\hline 1 & 4,198 & 41,984 \\
2 & 1,325 & 13,248 \\
3 & 1,193 & 11,927 \\
Total & 6,716 & 67,159 \\
\hline
\end{tabular}

Tabel diatas menunjukkan bahwa terdapat tiga faktor yang memiliki nilai eigenvalue

lebih besar dari satu. Penelitian ini mampu menjelaskan faktor yang menjadi pertimbangan konsumen dalam keputusan pembelian buah-buahan segar di Moena Fresh Bali sebesar 67,159\% sedangkan sisanya 32,841\% merupakan faktor lain yang tidak tercakup dalam hasil faktor.

Berdasarkan pada Tabel 3 diketahui bahwa hasil penelitian ini terbentuk tiga faktor baru dan masing-masing dimensi penyusun faktornya akan disajikan pada Tabel 4 dibawah ini. 
Tabel 4.

Component Matrix

\begin{tabular}{lccc}
\hline & \multicolumn{3}{c}{ Component } \\
\cline { 2 - 4 } & 1 & 2 & 3 \\
\hline Pendapatan & 0,241 & 0,143 & 0,841 \\
Jenis buah & 0,298 & 0,841 & $-0,006$ \\
Kesegaran buah & 0,727 & 0,451 & $-0,117$ \\
Kebersihan buah & 0,815 & 0,257 & 0,010 \\
Packaging & 0,657 & $-0,440$ & 0,269 \\
Harga & 0,658 & $-0,181$ & 0,427 \\
Kebersihan rak & 0,769 & $-0,184$ & $-0,257$ \\
Pelayanan pramuniaga & 0,802 & $-0,069$ & $-0,207$ \\
Suhu toko & 0,599 & $-0,194$ & $-0,327$ \\
Aroma toko & 0,633 & $-0,161$ & $-0,034$ \\
\hline
\end{tabular}

Tabel Component Matrix di atas menunjukkan distribusi dari 10 variabel pada ketiga komponen faktor yang terbentuk. Masing-masing faktor memuat kumpulan variabel- variabel yang memiliki korelasi dengan faktor tersebut yang ditunjukkan dengan nilai factor loading tertinggi dan menyeleksi kembali setiap variabel dari faktor yang terbentuk harus memiliki factor loading lebih besar dari 0,5.

Langkah selanjutnya adalah menentukan hubungan antara variabel asal dengan faktor yang terbentuk melalui component score coefficient matrix.

Tabel 5.

Component Score Coefficient Matrix

\begin{tabular}{lccc}
\hline & \multicolumn{3}{c}{ Component } \\
\cline { 2 - 4 } & 1 & 2 & 3 \\
\hline Pendapatan & 0,057 & 0,108 & $\mathbf{0 , 7 0 5}$ \\
Jenis buah & 0,071 & $\mathbf{0 , 6 3 5}$ & $-0,005$ \\
Kesegaran buah & $\mathbf{0 , 1 7 3}$ & 0,34 & $-0,098$ \\
Kebersihan buah & $\mathbf{0 , 1 9 4}$ & 0,194 & 0,008 \\
Packaging & $\mathbf{0 , 1 5 6}$ & $-0,332$ & 0,226 \\
Harga & $\mathbf{0 , 1 5 7}$ & $-0,136$ & 0,358 \\
Kebersihan rak & $\mathbf{0 , 1 8 3}$ & $-0,139$ & $-0,216$ \\
Pelayanan pramuniaga & $\mathbf{0 , 1 9 1}$ & $-0,052$ & $-0,173$ \\
Suhu toko & $\mathbf{0 , 1 4 3}$ & $-0,147$ & $-0,274$ \\
Aroma toko & $\mathbf{0 , 1 5 1}$ & $-0,121$ & $-0,028$ \\
\hline
\end{tabular}

Berdasarkan hasil analisis, nilai skor faktor untuk setiap variabel dijelaskan pada persamaan umum skor faktor dibawah ini. 


$$
\begin{aligned}
\mathrm{F} 1= & 0,173 \mathrm{X} 3+0,194 \mathrm{X} 4+0,156 \mathrm{X} 5+0,157 \mathrm{X} 6+0,183 \mathrm{X} 7+0,191 \mathrm{X} 8+0,143 \\
& \mathrm{X} 9+0,151 \mathrm{X} 10 \\
\mathrm{~F} 2= & 0,635 \mathrm{X} 2 \\
\mathrm{~F} 3= & 0,705 \mathrm{X} 1
\end{aligned}
$$

Langkah terakhir dalam memfaktorkan adalah pemberian nama untuk faktor yang terbentuk mencerminkan karakteristik dari variabel-variabel yang membentuknya.

Tabel 6.

Hasil Analisis Faktor-faktor yang Mempengaruhi Keputusan Konsumen dalam Pembelian Buah-buahan di Moena Fresh

\begin{tabular}{lcclc}
\hline Faktor Komponen & Eigenvalues & $\begin{array}{c}\text { Persentase } \\
\text { of variance }\end{array}$ & \multicolumn{1}{c}{ Variabel asal } & $\begin{array}{c}\text { Score } \\
\text { factor }\end{array}$ \\
\hline & & & Kesegaran buah & 0,173 \\
& & Kebersihan buah & 0,194 \\
& & & Packaging & 0,156 \\
Faktor lingkungan & 4,198 & \multirow{2}{*}{41,984} & Harga & 0,157 \\
& & & Kebersihan rak & 0,183 \\
& & & Pelayanan & 0,191 \\
& & & Sramuniaga & 0,143 \\
& & & Aroma ruangan & 0,151 \\
Faktor psikologis & 1,325 & 13,248 & Jenis buah & \\
Faktor perbedaan & 1,193 & 11,927 & Pendapatan & 0,635 \\
individual & & & 0,705 \\
\hline
\end{tabular}

Berdasarkan hasil analisis pada Tabel 6 diatas mengenai faktor-faktor yang mempengaruhi keputusan konsumen dalam pembelian buah-buahan di Moena Fresh dapat dijelaskan sebagai berikut.

1. Faktor lingkungan

Faktor pertama yang mempengaruhi keputusan pembelian buah-buahan segar di Moena Fresh yaitu memiliki angka eigenvalues sebesar 4,198 karena angka tersebut merupakan eigenvalues terbesar, maka faktor ini dapat menerangkan keragaman data sebesar 39,047\%.

Apabila dibandingkan dengan penelitian Delita, kedua penelitian ini memiliki persamaan pada faktor pertama yaitu faktor lingkungan, namun variabel-variabel yang masuk kedalam faktor ini berbeda. Faktor lingkungan pada penelitian Delita hanya mencakup tiga variabel yaitu pencahayaan, suhu ruangan, dan aroma ruangan sedangkan dalam penelitian ini faktor lingkungan mencakup delapan variabel yaitu kesegaran buah, kebersihan buah, packaging, harga, kebersihan rak, pelayanan pramuniaga, suhu toko dan aroma toko.

Berdasarkan hasil penelitian maka dapat disimpulkan bahwa konsumen Moena Fresh tersebut lebih mengutamakan situasi lingkungan toko yang senyaman 
mungkin sehingga konsumen merasa leluasa saat melakukan pembelian. Pihak Moena Fresh harus selalu menjaga kebersihan buah, kesegaran buah, packaging, kebersihan rak, suhu dan aroma toko serta dalam menetapkan harga, Moena Fresh juga harus memperhatikan harga yang ditawarkan supaya dapat dijangkau oleh seluruh konsumen.

2. Faktor psikologis

Kondisi buah-buahan dapat menjelaskan keragaman sebesar $13,248 \%$ dengan eigenvalues sebesar 1,325. Faktor ini mencakup satu variabel yaitu keragaman jenis buah. Keragaman jenis buah ini biasanya timbul berdasarkan atas selera atau keinginan konsumen itu sendiri maupun selera keluarga konsumen. Apabila dibandingkan dengan penelitian Delita, kedua penelitian ini memiliki perbedaan, dimana faktor kedua dalam penelitian Delita mencakup variabel kesegaran dan kebersihan sayuran sehingga faktor tersebut dinamai faktor kondisi sayuran.

3. Faktor perbedaan individual

Faktor komponen ketiga memiliki nilai eigenvalues 1,193 dan menjelaskan keragaman data sebesar 11,927\%. Faktor ini terdiri dari satu variabel yaitu pendapatan. Tingkat pendapatan yang dimiliki antar konsumen Moena Fresh berbeda-beda sehingga saat melakukan proses pembelian konsumen melihat terlebih dahulu anggaran yang dimiliki untuk menentukan buah apa saja yang dapat dibeli. Apabila dibandingkan dengan penelitian Delita, kedua penelitian ini memiliki perbedaan, dimana faktor ketiga dalam penelitian Delita mencakup variabel harga, kebersihan rak, pramuniaga dan pendapatan sehingga faktor tersebut dinamai faktor harga. Penamaan faktor pada faktor ketiga penelitian Delita ini dirasa kurang tepat karena adanya variabel kebersihan rak dan pramuniaga yang masuk kedalam bentuk faktor tersebut.

\section{Simpulan dan Saran}

\subsection{Simpulan}

Berdasarkan pada hasil dan pembahasan dalam penelitian ini terhadap keputusan pembelian buah-buahan di Moena Fresh adapun simpulan sebagai berikut.

1. Proses pengambilan keputusan pembelian buah-buahan yang dilalui oleh konsumen Moena Fresh yaitu tahap pengenalan kebutuhan mengenai kepentingan buah, tahapan pencarian informasi, kemudian evaluasi alternatif, tahapan pembelian, dan terakhir tahapan pasca pembelian.

2. Faktor-faktor yang mempengaruhi konsumen dalam memutuskan pembelian buah- buahan segar di Moena Fresh terdiri atas faktor eksternal dan faktor internal. Faktor eksternal terdiri dari faktor lingkungan yang meliputi variabel kesegaran buah, kebersihan buah, packaging, harga, kebersihan rak, pelayanan pramuniaga, suhu toko, serta aroma toko. Faktor internal terdiri atas faktor psikologis yang meliputi variabel jenis buah dan faktor perbedaan individu yang meliputi variabel pendapatan konsumen. Faktor tersebut mampu menjelaskan sebesar $67,16 \%$ faktor yang menjadi pertimbangan konsumen 
dalam keputusan pembelian buah-buahan segar di Moena Fresh sedangkan $32,84 \%$ merupakan faktor lain yang tidak tercakup dalam hasil faktor.

\subsection{Saran}

Adapun beberapa saran yang dapat diberikan untuk pengembangan kemajuan perusahaan Moena Fresh sebagai berikut.

a. Moena Fresh sebaiknya selalu memperhatikan ketersediaan buah-buahan pada display rak supaya tidak adanya kekosongan produk.

b. Faktor lain yang dapat dipertimbangkan oleh Moena Fresh adalah seperti iklan dan situasi psikologis konsumen.

c. Kepada mahasiswa yang ingin melanjutkan penelitian ini disarankan untuk menggunakan analisis faktor eksploratori dan jumlah variabel diperbanyak.

\section{Ucapan Terimakasih}

Terimakasih penulis ucapkan kepada seluruh pihak yang telah membantu dalam melaksanakan penelitian dan membimbing penulis sehingga hasil penelitian ini dapat dipublikasikan dalam -jurnal . Semoga hasil penelitian ini dapat bermanfaat sebagaimana mestinya.

\section{Daftar Pustaka}

Arikunto, Suharsimi. 2009. Dasar-Dasar Evaluasi Pendidikan, Jakarta: Bumi Aksara. Basis Data Konsumsi Pangan. 2014. Konsumsi Buah-buahan per Kapita dalam Rumah

Tangga Setahun di Indonesia pada tahun 2013 s/d 2014. Diunduh pada https://aplikasi2.pertanian.go.id. Diakses pada tanggal 15 Oktober 2016.

Binus University, 2014. Uji_ Validitas dan Uji Realibilitas. Diunduh pada http://qmc.binus.ac.id/. Diakses tanggal 1 Februari 2017.

Delita, Nova. 2008. Analisis Perilaku Konsumen Sayuran Segar Pada Supermarket Foodmart Di Plaza Ekalokasari Bogor. Diunduh http://repository.ipb.ac.id diakses tanggal 15 Oktober 2016.

Dirjen Hortikultura. 2012. RKT-Ditjen-Hortikultura. Di unduh pada http://sakip.pertanian.go.id. Di akses pada tanggal 10 November 2016.

Kusmintarti, dkk. 2010. Analisis Pengaruh Kredibilitas Merek Terhadap Sensitivitas Harga Konsumen Analysis Of Effect Of Brand Credibility On Consumers' Price Sensitivity. Jurnal Vol. 13 No. 1 Januari 2010 ISSN. 1411-0199 44.

Moena Fresh. 2016. Data Penjualan Moena Fresh selama tahun 2013-2015. Denpasar

Setyani, Lita.T. 2006. Analisis Perilaku Konsumen dalam Membeli Jeruk Medan di Pasar Modern di Surakarta (Kasus di Hypermart Solo Grand Mall). Skripsi S1 Fakultas Pertanian Universitas Negeri Surakarta.

Tenaya, Narka. 2009. Bahan Kuliah Ekonometrika Program Studi Agribisnis. Fakultas Pertanian Universitas Udayana.

Wibowo, Hendro. 2013. Bisnis Ritel Tradisional atau Ritel Modern yang Berpeluang. 
Diakses pada http://www.depoknews.id. Diunduh pada tanggal 10 november 2016. 